\title{
The Level of Osteoporosis Knowledge and the Related Factors Among Women Who Attended iskenderun Public Education Center Courses
}

\author{
iskenderun Halk Eğitim Merkezi Kurslarına Katılan Kadınların Osteoporoz \\ Bilgi Düzeyi ve ilişskili Faktörler
}

Eastern Mediterranean University Faculty of Health Sciences, Department of Nutrition and Dietetics, Gazimağusa, KKTC

\section{Abstract}

Objective: This study aimed to evaluate the levels of osteoporosis knowledge and self-efficacy and the related factors.

Materials and Methods: The study was conducted with 419 women aged between 19 and 60 years who attended the courses provided by Iskenderun Public Education Center. A questionnaire including the osteoporosis knowledge test (OKT) and osteoporosis self-efficacy scale (OSES) scores was applied by face to face interview method, the weight and height measurements were performed in accordance with the techniques.

Results: The women older than 23 years of age had higher total OKT scores than the women younger than 23 years. The total OKT scores of the women with bachelor's degree were 12.9 times higher than those of unschooled literate women. The OSES-exercise scores of selfemployed women were 2.4 times higher than those of housewives. A relationship was determined between the OKT and OSES total scores, OKT-nutrition and OSES-calcium, and OKT-exercise and OSES-exercise scores.

Conclusion: Women participating in İskenderun Public Education Center courses have low levels of osteoporosis knowledge and self-efficacy. Age, level of education, and occupation are important demographic factors affecting these levels. Further multicenter studies are needed to evaluate calcium intake and physical activity levels.

Keywords: Osteoporosis, knowledge, self-efficacy, woman

\section{Öz}

Amaç: Bu çalışmanın amacı osteoporoz bilgi ve öz-etkililik düzeyleri ile ilişkili faktörlerin değerlendirilmesidir.

Gereç ve Yöntem: Çalışma İskenderun Halk Eğitim Merkezi kurslarına katılan 19-60 yaş grubu 419 kadın ile yürütülmüştür. Osteoporoz bilgi düzeyi ölçeği (OKT) ve Osteoporoz öz-etkililik ölçeğini (OSS) kapsayan anket yüz yüze görüşme yöntemi ile uygulanmıs, vücut ağırlığı ve boy uzunluğu ölçümleri tekniklerine uygun olarak yapılmıştır.

Bulgular: Toplam OKT puanları yaşı >23 yıl olanlarda $\leq 23$ yıl olanlara kıyasla daha yüksektir. Lisans mezunlarının toplam OKT puanları okuryazarlara kıyasla 12,9 kat daha yüksektir. OSS-egzersiz puanları serbest meslek sahibi kadınlarda ev hanımlarına kıyasla 2,4 kat daha yüksektir. OKT ve OSS toplam puanları, OKT-beslenme ve OSS-kalsiyum, OKT-egzersiz ve OSS-egzersiz puanları arasında ilişki saptanmıştır.

Sonuç: İskenderun Halk Eğitim Merkezi kurslarına katılan kadınların osteoporoz bilgi ve öz-etkililik düzeyleri düşüktür. Yaş, eğitim düzeyi ve meslek osteoporoz bilgi ve öz-etkililik düzeylerini etkileyen önemli demografik faktörlerdir. Çok merkezli, kalsiyum alım miktarı ve fiziksel aktivite düzeylerinin değerlendirileceği daha ileri çalışmalara ihtiyaç vardır.

Anahtar kelimeler: Osteoporoz, bilgi, öz-etkililik, kadın

\section{Introduction}

Osteoporosis is a skeletal system disease characterized by low bone mass and impaired bone structure, which is associated with a high risk of fracture. Osteoporosis is a silently progressive disease; no clinical symptoms are observed until a fracture occurs $(1,2)$. The World Health Organization defines osteoporosis as "a bone mineral density that lies 2.5 standard deviations (SD) or more below the average value for young healthy women (a t-score of <-2.5 SD)" (3). The risk of osteoporosis is related to genetic and environmental factors. Gender, age, body mass index (BMI), alcohol consumption, smoking, inadequate calcium intake, and insufficient physical activity are associated with an increased risk of osteoporosis and osteoporotic fractures. Formation of the bone mass continues from birth to adulthood

Address for Correspondence/Yazıșma Adresi: Ceren Gezer Ass. Prof., Eastern Mediterranean University Faculty of Health Sciences, Department of Nutrition and Dietetics, Gazimağusa, KKTC Phone: +90 3926303003 E-mail: ceren.gezer@emu.edu.tr ORCID ID: orcid.org/0000-0002-5647-0103 Received/Geliş Tarihi: 26.01.2019 Accepted/Kabul Tarihi: 17.03.2019 
and reaches the peak at puberty (4). Therefore, information on osteoporosis and self-efficacy should be provided at a young age, and exposure to environmental risk factors should be avoided in order to reduce the risk of osteoporosis (5-7). According to the statistics of the International Osteoporosis Foundation, osteoporosis is expected to affect 200 million women worldwide. Osteoporosis affects both men and women; however, osteoporotic fractures are mostly observed in post-menopausal period among women due to the increased post-menopausal bone loss. Female/male ratio of osteoporotic fractures is 1.6 (8). The results of the FRACTURK study showed that the prevalence of osteoporosis at the femoral neck was $7.5 \%$ and $33.3 \%$ among men and women in Turkey, respectively. The risk of life-long osteoporotic hip fracture for the individuals older than 50 years of age is 3.5\% in men and $14.6 \%$ in women (9). Therefore, osteoporosis knowledge and behaviors of young women in the premenopausal period should be evaluated in order to provide appropriate recommendations to prevent osteoporosis, which is an important public health issue around the world. This study aimed to evaluate the knowledge level and self-efficacy regarding osteoporosis among the women who attended the courses in public education center in İskenderun-Hatay, Turkey, and the related factors.

\section{Materials and Methods}

\section{Study Sample}

This study included 419 women aged between 19 and 60 years of age (mean age, 26.38 \pm 7.38 years) who attended the courses provided in the public education center in Iskenderun, a county in Hatay, between April and July 2016.

\section{Data Collection}

The study was approved by the Ethical Board of Scientific Research and Publication of Eastern Mediterranean University on 30.05.2016 with number 2016/28-12. All participants were asked to sign an informed consent form as per the Declaration of Helsinki. The data were collected using questionnaires and face-to-face interviews. The questionnaire form included questions regarding general socio-demographic information, osteoporosis knowledge test (OKT), osteoporosis self-efficacy scale (OSS).

OKT: This test was developed by Kim et al. (10) in 1991 and tested by Killç and Erci (6) for validity and reliability in Turkish. Subsequently, the OKT was revised by Atalay et al. (11). This revised test consists of 32 items with a mean score ranging from 0 to 32 . The two sub-dimensions of this scale include nutrition and exercise, which include 26 and 20 items, respectively, with 14 items in common. An increase in the total score indicates an increase in the level of knowledge.

OSS: Self-efficacy is important for individuals to adopt and implement an attitude, and their individual belief plays a role in overcoming the difficulties they may encounter in the future. The OSS scale was developed by Kim et al. (10) in 1991 in order to evaluate self-efficacy related to osteoporosis, and tested by Kilıç and Erci (6) for validity and reliability in Turkish study. This form assesses individuals' level of confidence in preventing osteoporosis. The scale includes two sub-dimensions evaluating the perception of exercise and calcium self-efficacy. Each subdimension is scored between 0 and 600 , and the total scale score ranges between 0 and 1200. An increase in the score indicates an increase in the perception of self-efficacy.

Anthropometric Measurements: The weight measurements of the participants were taken as barefoot, with light clothes on digital scale with a sensitivity of $0.1 \mathrm{~kg}$. The height of the participants was measured using a non-streching tape measure with the participants standing with their feet side by side and their head on the Frankfort plane. BMI is defined as the weight in kilograms divided by the square of the height in meters $\left(\mathrm{kg} / \mathrm{m}^{2}\right)$ According to the classification of the World Health Organization, individuals who have a BMI lower than $18.5 \mathrm{~kg} /$ $\mathrm{m}^{2}$ are considered as "underweight," those with a BMI from 18.5 to $24.9 \mathrm{~kg} / \mathrm{m}^{2}$ are considered as "normal" those with a BMI from 25.00 to $29.9 \mathrm{~kg} / \mathrm{m}^{2}$ are considered as "overweight" and those with a BMI over $30 \mathrm{~kg} / \mathrm{m}^{2}$ are considered as "obese" (12).

\section{Statistical Analysis}

The data were analyzed using the descriptive statistics of mean $(\mathrm{x}), \mathrm{SD}$, median, minimum and maximum values for quantitative variables and frequency (n), and percentage (\%) for qualitative variables. Student's t-test was used for the comparison of two independent groups while one-way analysis of variance (ANOVA) was performed for the comparison of more than two independent groups. In case of a significant difference, Tukey post-hoc test was performed to analyze the pairwise differences between the groups. Pearson correlation analysis was used to examine the associations between numerical variables. The factors that affect OKT and OSS were evaluated using the binary logistic regression analysis. The scales do not have predefined cut-off points; therefore, variables were transformed into binary using sample median values as a threshold for each scale and subscales (being below and above the sample median). All statistical analyses were performed using the SPSS 18.0 software program, and the $p$ values below 0.05 were considered to be statistically significant.

\section{Results}

Different age groups obtained different osteoporosis knowledge test-total (OKT-tot) and osteoporosis knowledge test-nutrition (OKT-nutr) scores. The women older than 23 years of age had higher scores than the women younger than 23 years of age $(p<0.05)$. Unschooled literate women obtained the lowest OKT and OSS scores, and while university students obtained the highest scores. A statistically significant difference was found between the OKT-tot, osteoporosis knowledge test-exercises (OKT-exc), and OKT-nutr scores of unschooled literate women and university students. In addition, the OKT-tot scores of 
unschooled literate women were lower than those of women in high school $(p<0.05)$. The OKT-exc scores of the women in primary-secondary school were lower than those of the women at university $(p<0.05)$. Self-employed women obtained the highest OSS scores, which were found to be statistically different compared to those of the students. No statistically significant difference was observed between the OKT and OSS scores of smokers and alcohol consumers (Table 1). The regression analysis indicated that the OKT-tot, OKT-exc, and OKT-nutr scores of the women in the high school group were 10.4, 5.3, and 4.8 times higher than those of the unschooled literate women, respectively $(p<0.05)$. The OKT-tot scores of the women at university were 12.9 times higher than those of the unschooled literate women $(p<0.05)$. The OKT-tot and OKT-exc scores of the working women were 3.8 and 3.2 times higher than those of the housewives, respectively $(p<0.05)$ (Table 2 ). The OSS-exc scores of the self-employed women were 2.4 times higher than those of the housewives $(p<0.05)$ (Table 3$)$. A positive weak relationship was observed between the OKTtot and OSS-tot scores $(r=0.192, p<0.001)$, the OKT-nutr and OSS-calcium scores $(r=0.193, p<0.001)$, and the OKT-exc and OSS-exc scores $(r=0.152, p=0.002)$ (Figure 1).

\section{Discussion}

This study showed that the participants had low OKT and OSS scores. The factors such as age, gender, education level, and socio-economic conditions affect osteoporosis knowledge level and self-efficacy. Highly educated women and women with a high income level have more knowledge and awareness about osteoporosis (13). Along with other factors, age has an effect on the osteoporosis knowledge level. The results of this study showed that OKT-tot scores of the women older than 23 years of age were higher than those of the women younger than 23 years of age $(p<0.05)$. In a study conducted with women in Ankara, Turkey it has been found that 18- to 35-year-old women had lower osteoporosis awareness (14). The unschooled literate women had the lowest osteoporosis knowledge level, while the university students had the highest level $(p<0.05)$. The OKT-tot, OKT-exc, and OKT-nutr scores of the women at university were $12.9,6.3$, and 5.1 times higher than those of the unschooled literate women $(p<0.05)$, respectively. This study showed that young women with a high level of education had a high level of knowledge about osteoporosis. The results of this study were consistent with those obtained in a similar study conducted in Turkey in that the osteoporosis knowledge level of women was low and that young age and higher education level were related to an increase in the osteoporosis knowledge level (15). Two separate studies conducted in Poland and Turkey reported similar results to those obtained in the present study $(16,17)$. The results of a study carried out in Vietnam showed that women with a high level of education had high osteoporosis knowledge levels (18). Another study conducted with premenopausal and post-menopausal women in Turkey reported that the women's osteoporosis knowledge level of was generally low, although the women with higher education level had higher knowledge levels (19). In a study conducted with women and men in the United States of America determined that the osteoporosis knowledge level increased with age; however, no relation was observed between the level of education and the osteoporosis knowledge level (20). A study carried out with men and women in Turkey showed that increased in the education level is related to a higher level of osteoporosis awareness (21). The results of another study conducted with women and men in Turkey showed that the men's education level was higher than that of the women, but the osteoporosis knowledge levels of women were higher than those of men (22). No difference was observed between the osteoporosis self-efficacy, age, and education levels among the participants in the present study. A previous study conducted with women in Turkey showed a linear relation between the years of education and osteoporosis self-efficacy level (23). In addition, age was found to be related to the osteoporosis knowledge and osteoporosis self-efficacy of women (24).

The OKT-tot and OKT-exc scores of the working women were 3.8 and 3.2 times higher than those of the housewives, respectively. Self-employed women obtained the highest OSS scores, which were found to be statistically different compared to those of the students. The OSS-exc scores of the selfemployed women were 2.4 times higher than those of the housewives $(p<0.05)$. The results of a study conducted in Saudi Arabia showed that the knowledge level and self-efficacy differed by occupation (25). Thus, self-efficacy, which means the belief in oneself about overcoming the difficulties that may arise in the future, can be affected by individuals' occupation and skills. The present study showed no statistical difference between the OKT and OSS scores of smokers and alcohol consumers with respect to their BMI. Alcohol consumption and a high $\mathrm{BMI}$ are the factors that increase the risk of osteoporosis, and therefore, appropriate measures should be implemented to raise an awareness on this subject.

Trainings provided to women for prevention of osteoporosis were effective in increasing their knowledge about osteoporosis $(26,27)$. In addition, it was reported that increased level of knowledge did not cause behavioral changes and that the perceptions and beliefs related to osteoporosis were dependent on the individuals' cultural background $(28,29)$. Therefore, strategies should be developed to ensure behavioral changes and increase the individuals' osteoporosis knowledge level (30). In addition, self-efficacy is effective for individuals to develop a behavior. Thus, development of novel strategies to evaluate and improve the self-efficacy is of great importance. A randomized controlled study showed that women were trained about osteoporosis, and their osteoporosis knowledge levels increased after two years, whereas their osteoporosis selfefficacy had not changed (31). Similarly, another study showed that at the end of the training provided to the individuals with or without a history of osteoporosis in their families, no change 
Table 1. Osteoporosis knowledge and osteoporosis self-efficacy scores based on the age, education level, occupation and body mass index

\begin{tabular}{|c|c|c|c|c|c|c|}
\hline & $\begin{array}{l}\text { OKT-tot } \\
\pm \text { SD } \\
\text { median } \\
\text { (min-max) }\end{array}$ & $\begin{array}{l}\text { OKT-exc } \\
\pm \text { SD } \\
\text { median } \\
\text { (min-max) }\end{array}$ & $\begin{array}{l}\text { OKT-nutr } \\
\pm \text { SD median } \\
\text { (min-max) }\end{array}$ & $\begin{array}{l}\text { OSS-tot } \\
\pm \text { SD } \\
\text { median } \\
\text { (min-max) }\end{array}$ & $\begin{array}{l}\text { OSS-exc } \\
\pm \text { SD } \\
\text { median } \\
\text { (min-max) }\end{array}$ & $\begin{array}{l}\text { OSS-Ca } \\
\pm \text { SD } \\
\text { median } \\
\text { (min-max) }\end{array}$ \\
\hline \multicolumn{7}{|l|}{ Age (years) } \\
\hline$\leq 23$ & $\begin{array}{l}12.2 \pm 5.10 \\
13.0(0-23)\end{array}$ & $\begin{array}{l}7.9 \pm 3.87 \\
8.0(0-18.0)\end{array}$ & $\begin{array}{l}10.1 \pm 4.39 \\
11.0(0-20.0)\end{array}$ & $\begin{array}{l}737.4 \pm 276.68 \\
740.0(0-1200)\end{array}$ & $\begin{array}{l}367.4 \pm 147.11 \\
360.0(0-600)\end{array}$ & $\begin{array}{l}370.0 \pm 154.31 \\
360.0(0-600)\end{array}$ \\
\hline$>23$ & $\begin{array}{l}13.0 \pm 4.35 \\
13.0(0-24)\end{array}$ & $\begin{array}{l}8.1 \pm 3.44 \\
8.0(0-16)\end{array}$ & $\begin{array}{l}10.8 \pm 3.77 \\
11.0(0-21)\end{array}$ & $\begin{array}{l}750.7 \pm 264.82 \\
745.0(0-1200)\end{array}$ & $\begin{array}{l}363.0 \pm 147.14 \\
375.0(0-600)\end{array}$ & $\begin{array}{l}387.6 \pm 155.59 \\
405.0(0-600)\end{array}$ \\
\hline$p$ & 0.01 & 0.12 & 0.03 & 0.45 & 0.95 & 0.80 \\
\hline \multicolumn{7}{|l|}{ Smoking } \\
\hline No & $\begin{array}{l}12.6 \pm 4.81 \\
13.0(0-23)\end{array}$ & $\begin{array}{l}8.0 \pm 3.69 \\
8.0(0-18)\end{array}$ & $\begin{array}{l}10.5 \pm 4.16 \\
11.0(0-20)\end{array}$ & $\begin{array}{l}738.0 \pm 274.81 \\
740.0(0-1200)\end{array}$ & $\begin{array}{l}361.2 \pm 149.67 \\
360.0(0-600)\end{array}$ & $\begin{array}{l}376.8 \pm 155.13 \\
380.0(0-600)\end{array}$ \\
\hline Yes & $\begin{array}{l}12.5 \pm 4.61 \\
12.5(0-24)\end{array}$ & $\begin{array}{l}7.9 \pm 3.60 \\
8.0(0-16)\end{array}$ & $\begin{array}{l}10.4 \pm 3.99 \\
10.0(0-21)\end{array}$ & $\begin{array}{l}765.5 \pm 251.21 \\
780.0(0-1200)\end{array}$ & $\begin{array}{l}382.4 \pm 132.94 \\
415.0(0-600)\end{array}$ & $\begin{array}{l}383.1 \pm 154.89 \\
405.0(0-600)\end{array}$ \\
\hline$p$ & 0.71 & 0.89 & 0.63 & 0.24 & 0.07 & 0.75 \\
\hline \multicolumn{7}{|c|}{ Alcohol consumption } \\
\hline No & $\begin{array}{l}12.6 \pm 4.78 \\
13.0(0-24)\end{array}$ & $\begin{array}{l}8.0 \pm 3.68 \\
8.0(0-18)\end{array}$ & $\begin{array}{l}10.4 \pm 4.14 \\
11.0(0-21)\end{array}$ & $\begin{array}{l}745.1 \pm 269.80 \\
740.0(0-1200)\end{array}$ & $\begin{array}{l}365.9 \pm 146.27 \\
370.0(0-600)\end{array}$ & $\begin{array}{l}379.2 \pm 155.00 \\
380.0(0-600)\end{array}$ \\
\hline Yes & $\begin{array}{l}14.6 \pm 3.38 \\
15.5(9-19)\end{array}$ & $\begin{array}{l}9.5 \pm 2.94 \\
10.0(4-12)\end{array}$ & $\begin{array}{l}11.5 \pm 2.94 \\
12.0(7-16)\end{array}$ & $\begin{array}{l}586.6 \pm 312.51 \\
520.0(180-1000)\end{array}$ & $\begin{array}{l}300.0 \pm 191.10 \\
260.0(90-550)\end{array}$ & $\begin{array}{l}286.6 \pm 128.16 \\
290.0(90-450)\end{array}$ \\
\hline$p$ & 0.27 & 0.28 & 0.21 & 0.64 & 0.29 & 0.32 \\
\hline \multicolumn{7}{|l|}{ Education level } \\
\hline $\begin{array}{l}\text { Unschooled } \\
\text { literate }\end{array}$ & $\begin{array}{l}8.9 \pm 4.76^{a, b} \\
10.5(0-18)\end{array}$ & $\begin{array}{l}5.7 \pm 3.51^{c} \\
6.0(0-14)\end{array}$ & $\begin{array}{l}7.7 \pm 4.04^{\mathrm{e}} \\
8.5(0-15.0)\end{array}$ & $\begin{array}{l}647.1 \pm 341.70 \\
625.0(0-1200)\end{array}$ & $\begin{array}{l}336.4 \pm 194.16 \\
370.0(0-600)\end{array}$ & $\begin{array}{l}310.7 \pm 191.89 \\
325.0(0-600)\end{array}$ \\
\hline $\begin{array}{l}\text { Primary-secondary } \\
\text { School }\end{array}$ & $\begin{array}{l}11.8 \pm 4.38 \\
11.5(0-22.0)\end{array}$ & $\begin{array}{l}7.0 \pm 3.35^{d} \\
7.0(0-15.0)\end{array}$ & $\begin{array}{l}9.8 \pm 3.85 \\
10.0(0-19)\end{array}$ & $\begin{array}{l}763.2 \pm 299.48 \\
750.0(80-1200)\end{array}$ & $\begin{array}{l}374.8 \pm 163.81 \\
405.0(0-600)\end{array}$ & $\begin{array}{l}388.4 \pm 172.79 \\
410.0(0-600)\end{array}$ \\
\hline High school & $\begin{array}{l}12.6 \pm 4.92^{\mathrm{a}} \\
13.0(0-23)\end{array}$ & $\begin{array}{l}8.1 \pm 3.76 \\
8.0(0-17)\end{array}$ & $\begin{array}{l}10.4 \pm 4.29 \\
10.0(0-20)\end{array}$ & $\begin{array}{l}726.0 \pm 263.49 \\
710.0(0-1200)\end{array}$ & $\begin{array}{l}361.8 \pm 136.70 \\
350.0(0-600)\end{array}$ & $\begin{array}{l}364.1 \pm 152.81 \\
360.0(0-600)\end{array}$ \\
\hline University & $\begin{array}{l}13.3 \pm 4.56^{\mathbf{b}} \\
14.0(1-24)\end{array}$ & $\begin{array}{l}8.6 \pm 3.55^{c, d} \\
9.0(0-18)\end{array}$ & $\begin{array}{l}11.0 \pm 3.92^{\mathrm{e}} \\
11.0(0-21)\end{array}$ & $\begin{array}{l}767.6 \pm 257.89 \\
810.0(0-1200)\end{array}$ & $\begin{array}{l}368.6 \pm 147.66 \\
380.0(0-600)\end{array}$ & $\begin{array}{l}398.9 \pm 142.59 \\
410.0(0-600)\end{array}$ \\
\hline $\mathrm{p}$ & 0.03 & 0.02 & 0.01 & 0.25 & 0.80 & 0.06 \\
\hline \multicolumn{7}{|l|}{ Occupation } \\
\hline Housewife & $\begin{array}{l}12.6 \pm 4.56 \\
13.0(0-23)\end{array}$ & $\begin{array}{l}7.8 \pm 3.65 \\
8.0(0-18)\end{array}$ & $\begin{array}{l}10.4 \pm 3.93 \\
10.0(0-20)\end{array}$ & $\begin{array}{l}762.4 \pm 267.94 \\
755.0(0-1200)\end{array}$ & $\begin{array}{l}372.1 \pm 147.60 \\
380.0(0-600)\end{array}$ & $\begin{array}{l}390.2 \pm 155.4 \\
400.0(0-600)\end{array}$ \\
\hline Civil servant & $\begin{array}{l}13.1 \pm 5.29 \\
14.0(1-20)\end{array}$ & $\begin{array}{l}8.0 \pm 3.83 \\
8.0(1-14)\end{array}$ & $\begin{array}{l}11.0 \pm 4.83 \\
12.0(0-17)\end{array}$ & $\begin{array}{l}544.8 \pm 280.54 \\
740.0(0-1020) \\
\end{array}$ & $\begin{array}{l}335.0 \pm 139.66 \\
340.0(0-540)\end{array}$ & $\begin{array}{l}359.3 \pm 169.7 \\
400.0(0-600)\end{array}$ \\
\hline Self employed & $\begin{array}{l}13.4 \pm 4.57 \\
13.0(1-24)\end{array}$ & $\begin{array}{l}8.8 \pm 3.56 \\
9.0(0-16)\end{array}$ & $\begin{array}{l}10.9 \pm 3.91 \\
10.5(1-21)\end{array}$ & $\begin{array}{l}862.2 \pm 277.04^{f} \\
900.0(100-1200)\end{array}$ & $\begin{array}{l}423.3 \pm 166.01^{9} \\
460.0(0-600)\end{array}$ & $\begin{array}{l}438.8 \pm 147.58^{h} \\
475.0(60-600)\end{array}$ \\
\hline Worker & $\begin{array}{l}14.6 \pm 3.47 \\
15.5(8-20)\end{array}$ & $\begin{array}{l}9.3 \pm 2.84 \\
10.0(4-14)\end{array}$ & $\begin{array}{l}12.4 \pm 3.48 \\
12.0(6-18)\end{array}$ & $\begin{array}{l}643.1 \pm 232.28 \\
585.0(290-1010)\end{array}$ & $\begin{array}{l}304.3 \pm 104.68 \\
305.0(150-490)\end{array}$ & $\begin{array}{l}338.7 \pm 155.00 \\
300.0(120-580)\end{array}$ \\
\hline Student & $\begin{array}{l}12.1 \pm 5.12 \\
13.0(0-22)\end{array}$ & $\begin{array}{l}8.0 \pm 3.78 \\
8.0(0-17)\end{array}$ & $\begin{array}{l}10.1 \pm 4.40 \\
11.0(0-20) \\
\end{array}$ & $\begin{array}{l}703.5 \pm 267.08^{f} \\
710.0(0-1200) \\
\end{array}$ & $\begin{array}{l}351.1 \pm 142.00^{9} \\
340.0(0-600) \\
\end{array}$ & $\begin{array}{l}352.3 \pm 150.06^{\mathrm{h}} \\
350.0(0-600)\end{array}$ \\
\hline$p$ & 0.22 & 0.37 & 0.24 & 0.00 & 0.02 & 0.01 \\
\hline \multicolumn{7}{|l|}{ BMI $\left(\mathrm{kg} / \mathrm{m}^{2}\right)$} \\
\hline 18.5 & $\begin{array}{l}12.7 \pm 4.90 \\
14.0(0-22) \\
\end{array}$ & $\begin{array}{l}8.4 \pm 3.89 \\
9.0(0-15.0)\end{array}$ & $\begin{array}{l}10.3 \pm 4.35 \\
10.0(0-19) \\
\end{array}$ & $\begin{array}{l}724.8 \pm 248.10 \\
730.0(190-1200) \\
\end{array}$ & $\begin{array}{l}361.2 \pm 131.14 \\
370.0(0-600)\end{array}$ & $\begin{array}{l}363.6 \pm 145.39 \\
360.0(0-600)\end{array}$ \\
\hline $18.5-24.9$ & $\begin{array}{l}12.8 \pm 4.87 \\
13.0(0-24)\end{array}$ & $\begin{array}{l}8.2 \pm 3.71 \\
9.0(0-18)\end{array}$ & $\begin{array}{l}10.6 \pm 4.22 \\
11.0(0-21)\end{array}$ & $\begin{array}{l}753.7 \pm 273.02 \\
780.0(0-1200)\end{array}$ & $\begin{array}{l}366.3 \pm 147.59 \\
360.0(0-600)\end{array}$ & $\begin{array}{l}387.4 \pm 150.14 \\
400.0(0-600)\end{array}$ \\
\hline
\end{tabular}




\begin{tabular}{|c|c|c|c|c|c|c|}
\hline 25.0-29.9 & $\begin{array}{l}12.0 \pm 4.82 \\
12.5(0-23)\end{array}$ & $\begin{array}{l}7.4 \pm 3.74 \\
7.5(0-16)\end{array}$ & $\begin{array}{l}10.1 \pm 4.11 \\
10.0(0-20)\end{array}$ & $\begin{array}{l}732.6 \pm 281.94 \\
730.0(0-1200)\end{array}$ & $\begin{array}{l}370.0 \pm 151.04 \\
390.0(0-600)\end{array}$ & $\begin{array}{l}362.6 \pm 168.61 \\
360.0(0-600)\end{array}$ \\
\hline$\geq 30$ & $\begin{array}{l}13.3 \pm 2.90 \\
13.5(7-18)\end{array}$ & $\begin{array}{l}7.9 \pm 2.12 \\
7.5(4-11)\end{array}$ & $\begin{array}{l}10.8 \\
11.0(4-15)\end{array}$ & $\begin{array}{l}731.9 \pm 254.22 \\
680.0(0-1200)\end{array}$ & $\begin{array}{l}345.0 \pm 157.41 \\
345.0(0-600)\end{array}$ & $\begin{array}{l}386.9 \pm 158.23 \\
380.0(0-600)\end{array}$ \\
\hline$p$ & 0.46 & 0.25 & 0.68 & 0.85 & 0.88 & 0.49 \\
\hline Total & $\begin{array}{l}12.6 \pm 4.76 \\
13.0(0-24)\end{array}$ & $\begin{array}{l}8.0 \pm 3.67 \\
8.0(0-18)\end{array}$ & $\begin{array}{l}10.4 \pm 4.12 \\
11.0(0-21)\end{array}$ & $\begin{array}{l}743.7 \pm 270.90 \\
740.0(0-1200)\end{array}$ & $\begin{array}{l}365.3 \pm 146.96 \\
370.0(0-600)\end{array}$ & $\begin{array}{l}378.3 \pm 154.99 \\
380.0(0-600)\end{array}$ \\
\hline \multicolumn{7}{|c|}{$\begin{array}{l}\text { a, b, c, d, e, f, g, h: p<0.05, BMI: Body mass index, Tot: Total, Ca: Calcium, Exc: Exercises, Nutr: Nutrition, OSS: Osteo } \\
\text { test } \\
\text { a: OKT-tot scores of unschooled literate and high school graduates are statistically different from each other } \\
\text { b: OKT-tot scores of unschooled literate and university graduates are statistically different from each other } \\
\text { c: OKT-exc scores of unschooled literate and university graduates are statistically different from each other } \\
\text { d: OKT-exc scores of unschooled literate and high school graduates are statistically different from each other } \\
\text { : OKT-nutr scores of unschooled literate and university graduates are statistically different from each other } \\
\text { : OSS-tot scores of the self-employed and students are statistically different from each other } \\
\text { g: OSS-exc scores of the self-employed and students are statistically different from each other } \\
\text { h: OSS-Ca scores of the self-employed and students are statistically different from each other }\end{array}$} \\
\hline
\end{tabular}

\section{Table 2. The results of regression analysis of the variables related to the osteoporosis knowledge level}

\begin{tabular}{|c|c|c|c|c|c|c|c|c|c|}
\hline & \multicolumn{3}{|l|}{ OKT-tot } & \multicolumn{3}{|c|}{ OKT-exc } & \multicolumn{3}{|c|}{ OKT-nutr } \\
\hline & B (SE) & p & $\begin{array}{l}\text { Odds ratio } \\
(95 \% \mathrm{Cl})\end{array}$ & B (SE) & $\mathbf{p}$ & $\begin{array}{l}\text { Odds ratio } \\
(95 \% \mathrm{Cl})\end{array}$ & B (SE) & $\mathbf{p}$ & $\begin{array}{l}\text { Odds ratio } \\
(95 \% \mathrm{Cl})\end{array}$ \\
\hline Age & $\begin{array}{l}0.000 \\
(0.014)\end{array}$ & 0.975 & $\begin{array}{l}1.000 \\
(0.973-1.028)\end{array}$ & $\begin{array}{l}-0.003 \\
(0.014)\end{array}$ & 0.839 & $\begin{array}{l}0.997 \\
(0.970-1.025)\end{array}$ & $\begin{array}{l}0.000 \\
(0.014)\end{array}$ & 0.981 & $\begin{array}{l}1.000 \\
(0.973-1.028)\end{array}$ \\
\hline Smoking & $\begin{array}{l}-0.318 \\
(0.279)\end{array}$ & 0.254 & $\begin{array}{l}0.727 \\
(0.421-1.257)\end{array}$ & $\begin{array}{l}-0.122 \\
(0.275)\end{array}$ & 0.657 & $\begin{array}{l}0.885 \\
(0.517-1.517)\end{array}$ & $\begin{array}{l}-0.264 \\
(0.278)\end{array}$ & 0.341 & $\begin{array}{l}0.768 \\
(0.445-1.323)\end{array}$ \\
\hline Alcohol & $\begin{array}{l}0.852 \\
(0.887)\end{array}$ & 0.337 & $\begin{array}{l}2.344 \\
(0.412-13.338)\end{array}$ & $\begin{array}{l}1.697 \\
(1.119)\end{array}$ & 0.129 & $\begin{array}{l}5.459 \\
(0.609-48.957)\end{array}$ & $\begin{array}{l}1.022 \\
(0.887)\end{array}$ & 0.249 & $\begin{array}{l}2.778 \\
(0.489-15.794)\end{array}$ \\
\hline \multicolumn{10}{|c|}{ Education level } \\
\hline $\begin{array}{l}\text { Primary/ } \\
\text { secondary } \\
\text { school }\end{array}$ & $\begin{array}{l}1.925 \\
(1.071)\end{array}$ & 0.072 & $\begin{array}{l}6.858 \\
(0.840-56.001)\end{array}$ & $\begin{array}{l}1.025 \\
(0.809)\end{array}$ & 0.205 & $\begin{array}{l}2.788 \\
(0.571-13.622)\end{array}$ & $\begin{array}{l}1.017 \\
(0.810)\end{array}$ & 0.209 & $\begin{array}{l}2.766 \\
(0.565-13.539)\end{array}$ \\
\hline High school & $\begin{array}{l}2.349 \\
(1.052)\end{array}$ & 0.026 & $\begin{array}{l}10.470 \\
(1.331-82.375)\end{array}$ & $\begin{array}{l}1.681 \\
(0.782)\end{array}$ & 0.032 & $\begin{array}{l}5.372 \\
(1.161-24.863)\end{array}$ & $\begin{array}{l}1.585 \\
(0.784)\end{array}$ & 0.043 & $\begin{array}{l}4.877 \\
(1.049-22.673)\end{array}$ \\
\hline University & $\begin{array}{l}2.559 \\
(1.057)\end{array}$ & 0.015 & $\begin{array}{l}12.927 \\
(1.630-102.536)\end{array}$ & $\begin{array}{l}1.846 \\
(0.787)\end{array}$ & 0.019 & $\begin{array}{l}6.332 \\
(1.354-29.624)\end{array}$ & $\begin{array}{l}1.634 \\
(0.790)\end{array}$ & 0.039 & $\begin{array}{l}5.124 \\
(1.090-24.079)\end{array}$ \\
\hline \multicolumn{10}{|l|}{ Occupation } \\
\hline Civil servant & $\begin{array}{l}0.301 \\
(0.536)\end{array}$ & 0.575 & $\begin{array}{l}1.351 \\
(0.473-3.861)\end{array}$ & $\begin{array}{l}-0.347 \\
(0.535)\end{array}$ & 0.517 & $\begin{array}{l}0.707 \\
(0.248-2.016)\end{array}$ & $\begin{array}{l}0.409 \\
(0.535)\end{array}$ & 0.445 & $\begin{array}{l}1.505 \\
(0.527-4.298)\end{array}$ \\
\hline Self employed & $\begin{array}{l}-0.334 \\
(0.386)\end{array}$ & 0.387 & $\begin{array}{l}0.716 \\
(0.336-1.527)\end{array}$ & $\begin{array}{l}0.155 \\
(0.378)\end{array}$ & 0.681 & $\begin{array}{l}1.168 \\
(0.557-2.449)\end{array}$ & $\begin{array}{l}-0.254 \\
(0.386)\end{array}$ & 0.511 & $\begin{array}{l}0.776 \\
(0.364-1.653)\end{array}$ \\
\hline Worker & $\begin{array}{l}1.337 \\
(0.603)\end{array}$ & 0.027 & $\begin{array}{l}3.809 \\
(1.167-13.429)\end{array}$ & $\begin{array}{l}1.186 \\
(0.603)\end{array}$ & 0.049 & $\begin{array}{l}3.273 \\
(1.003-10.679)\end{array}$ & $\begin{array}{l}0.806 \\
(0.545)\end{array}$ & 0.139 & $\begin{array}{l}2.239 \\
(0.770-6.512)\end{array}$ \\
\hline Student & $\begin{array}{l}-0.111 \\
(0.262)\end{array}$ & 0.670 & $\begin{array}{l}3.809 \\
(1.167-12.429)\end{array}$ & $\begin{array}{l}-0.245 \\
(0.261)\end{array}$ & 0.348 & $\begin{array}{l}0.783 \\
(0.470-1.306)\end{array}$ & $\begin{array}{l}-0.133 \\
(0.262)\end{array}$ & 0.612 & $\begin{array}{l}0.876 \\
(0.524-1.463)\end{array}$ \\
\hline BMI $\left(\mathrm{kg} / \mathrm{m}^{2}\right)$ & $\begin{array}{l}0.012 \\
(0.026) \\
\end{array}$ & 0.637 & $\begin{array}{l}1.012 \\
(0.962-1.066) \\
\end{array}$ & $\begin{array}{l}-0.013 \\
(0.026) \\
\end{array}$ & 0.614 & $\begin{array}{l}0.987 \\
(0.938-1.039) \\
\end{array}$ & $\begin{array}{l}0.020 \\
(0.026) \\
\end{array}$ & 0.446 & $\begin{array}{l}1.020 \\
(0.969-1.074) \\
\end{array}$ \\
\hline Stable & $\begin{array}{l}-2.781 \\
(1.272)\end{array}$ & 0.029 & 0.062 & $\begin{array}{l}-1.292 \\
(1.048)\end{array}$ & 0.218 & 0.275 & -2.197 & 0.038 & 0.111 \\
\hline
\end{tabular}

was observed in the participants' osteoporosis self-efficacy (32). The present study showed a low positive relationship between OKT-tot and OSS-tot, between OKT-nutr and OSS-
Ca, and between OKT-exc and OSS-exc $(r=0.192, p<0.001$, $r=0.193, p<0.001, r=0.152, p=0.002$ respectively). Although the correlation coefficients showed a weak association between 
Table 3. The results of regression analysis of the variables related to the osteoporosis self-efficacy

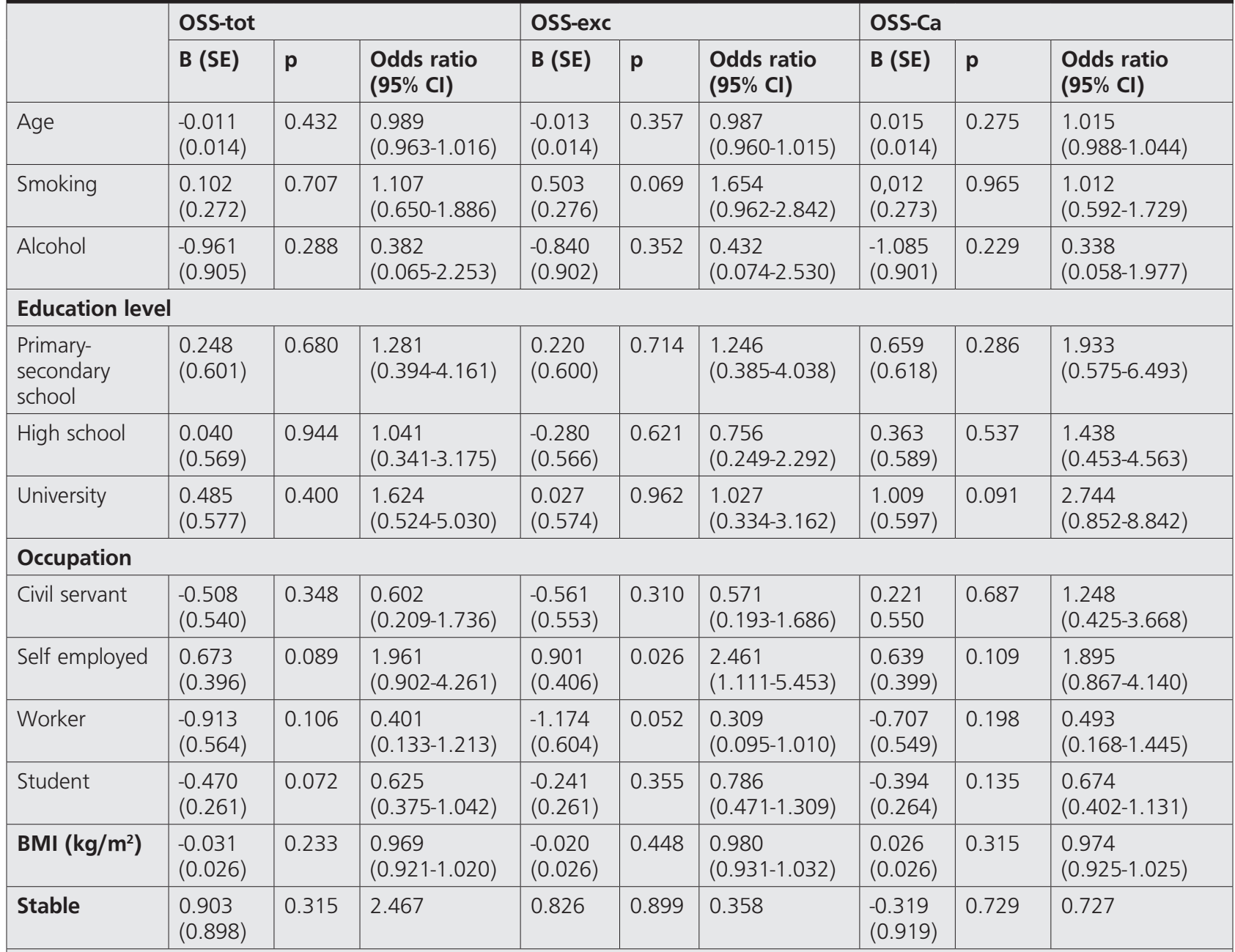

p <0.05, BMl: Body mass index, Ca: Calcium, Cl: Confidence interval, Exc: Exercises, OSS: Osteoporosis self-efficacy scale, SE: Standard error, Tot: Total smoking reference category: does not smoke, alcohol reference category: does not drink, education level reference: unschooled literate, occupation reference category: housewife
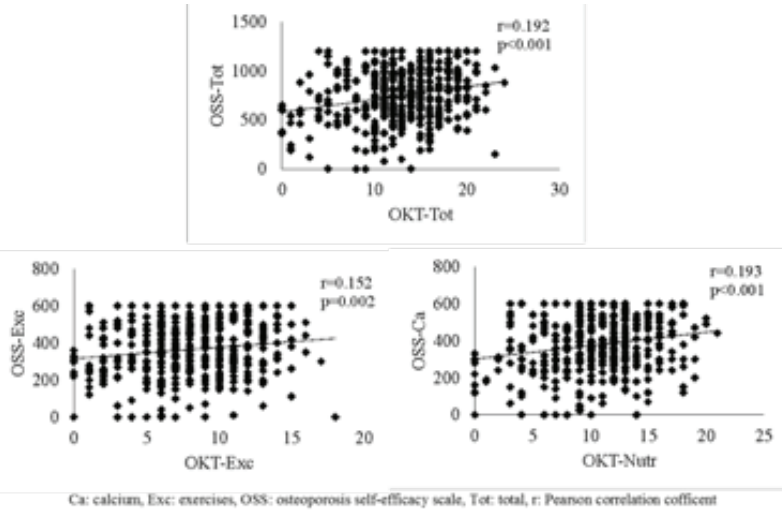

Figure 1. The relationship between osteoporosis knowledge and osteoporosis self-efficacy scores $(n=419)$

the variables, the considerably large sample size obtained in this study enabled us to show the significance of these correlations. Another study conducted in Turkey showed a similar relationship between the OKT and OSS scores of the women who were admitted to orthopedic clinics (24).

\section{Conclusion}

In conclusion, this study showed a low the osteoporosis knowledge level and self-efficacy among the women. Age, level of education, and occupation are important demographic factors which affect osteoporosis knowledge level and self-efficacy. The $80 \%$ or $90 \%$ of peak bone mass is acquired in late adolescence; therefore, providing theoretical courses in secondary and high schools may increase individuals' osteoporosis knowledge level. In addition, providing information on the physical activities and nutrition that may lead to changes in lifestyles can contribute to reducing the risk of osteoporosis and promoting public health. Limitations of this study include the facts that the study was conducted at only one center, and dietary consumptions and physical activities were not recorded. Thus, there is a need for further multicenter studies which also assess calcium intake and physical activity level.

\section{Ethics}

Ethics Committee Approval: The study was approved by the Ethical Board of Scientific Research and Publication of Eastern 
Mediterranean University dated 30.05.2016 and numbered 2016/28-12.

Informed Consent: Informed consent was obtained from all participants

Peer-review: Externally peer-reviewed

\section{Authorship Contributions}

Concept: C.G., Design: C.G., E.O., Data Collection or Processing: E.O., Analysis or Interpretation: C.G., Literature Search: C.G., Writing: C.G., E.O.

Conflict of Interest: No conflict of interest was declared by the authors

Financial Disclosure: The authors declared that this study received no financial support.

\section{References}

1. Kling JM, Clarke BL, Sandhu NP. Osteoporosis prevention, screening, and treatment: a review. J Womens Health (Larchmt) 2014:23:563-72.

2. Siris ES, Adler R, Bilezikian J, Bolognese M, Dawson-Hughes B, Favus MJ, et al. The clinical diagnosis of osteoporosis: a position statement from the National Bone Health Alliance Working Group. Osteoporos Int 2014:25:1439-43.

3. World Health Organisation. WHO scientific group on the assessment of osteoporosis at primary health care level. Geneva World Health Organisation; 2007.

4. Sözen T, Özışık L, Başaran NÇ. An overview and management of osteoporosis. Eur J Rheumatol 2017:4:46-56.

5. Sedlak CA, Doheny MO, Jones SL. Osteoporosis prevention in young women. Orthop Nurs 1998;17:53-60.

6. Kılıç D, Erci B. Osteoporoz Sağlik İnanç Ölçeği, Osteoporoz Öz-Etkililik/Yeterlik Ölçeği Ve Osteoporoz Bilgi Testi'nin Geçerlilik Ve Güvenirliği. Atatürk Üniv. Hemşirelik Yüksekokulu Dergisi 2004:7:89-102.

7. Rizzoli R, Bischoff-Ferrari H, Dawson-Hughes B, Weaver C Nutrition and bone health in women after the menopause. Womens Health (Lond) 2014;10:599-608.

8. International Osteoporosis Foundation. https://www. iofbonehealth.org/facts-statistics. 24th June 2018

9. Tuzun S, Eskiyurt N, Akarirmak U, Saridogan M, Senocak M Johansson $\mathrm{H}$, et al. Incidence of hip fracture and prevalence of osteoporosis in Turkey: the FRACTURK study. Osteoporos Int 2012;23:949-55.

10. Kim KK, Horan ML, Gendler P. Osteoporosis Knowledge Test, Osteoporosis Health Belief Scale, and Osteoporosis Self-Efficacy Scale. Allendale, Grand Valley State University, MI: 1991.

11. Atalay NŞ, Akkaya N, Şahin F. The Psychometric Properties of the Turkish Version of Revised 2011-Osteoporosis Knowledge Test. Turk J Osteoporos 2015;21:127-31.

12. World Health Organisation. Obesity: Preventing and managing the global epidemic. Geneva World Health Organisation; 2000.

13. Yeap SS, Goh EM, Das Gupta E. Knowledge about osteoporosis in a Malaysian population. Asia Pac J Public Health 2010;22:233-41.

14. Koç A, Raypak C, Yıkılkan H, Akbıyık I, Görpelioğlu S. Knowledge attitude and behaviour levels bout osteoporosis among 18-35 years old women. Turk J Osteoporos 2016:22:11-6.
15. Çıtıl R, Özdemir M, Poyrazoğlu S, Balcı E, Aykut M, Öztürk Y. Women's knowledge and attitude about osteoporosis at Kayseri Melikgazi Health Group Headship's. Osteoporoz Dünyasından. 2007;13:60-6.

16. Drozdzowska B, Pluskiewicz W, Skiba M. Knowledge about osteoporosis in a cohort of Polish females: the influence of age, level of education and personal experiences. Osteoporos Int 2004; 15:645-8

17. Gemalmaz A, Oge A. Knowledge and awareness about osteoporosis and its related factors among rural Turkish women. Clin Rheumatol 2008:27:723-8.

18. Nguyen NV, Dinh TA, Ngo QV, Tran VD, Breitkopf CR. Awareness and knowledge of osteoporosis in Vietnamese women. Asia Pac J Public Health 2015;27:NP95-105.

19. Okumus M, Ceceli E, Tasbas O, Kocaoglu S, Akdogan S Borman P. Educational status and knowledge level of pre- and postmenopausal women about osteoporosis and risk factors: a cross-sectional study in a group of Turkish female subjects. J Back Musculoskelet Rehabil 2013:26:337-43.

20. Ailinger RL, Braun MA, Lasus $H$, Whitt $K$. Factors influencing osteoporosis knowledge: a community study. J Community Health Nurs 2005;22:135-42

21. Aksu A, Zinnuroğlu M, Karaoğlan B, Akın S, Kutsal YG, Atalay F et al. Osteoporosis, education status and knowledge level research results. Osteoporoz Dünyasından 2005;11:120-7.

22. Altın E, Karadeniz B, Türkyön F, Baldan F, Akkaya N, Atalay NŞ, et al. The Comparison of Knowledge Level and Awareness of Osteoporosis between Women and Men. Turk J Osteoporos 2014;20:98-103.

23. Arslan SA, Daşkapan A, Atalay DK, Tüzün EH, Korkem D. Osteoporosis knowledge level of the women living in the city of Kırıkale. Turk J Physiotherapy and Rehabilitation Dergisi 2015;26:120-7.

24. Ozturk A, Sendir M. Evaluation of knowledge of osteoporosis and self-efficacy perception of female orthopaedic patients in Turkey. J Nurs Healthc Chronic III 2011:3:319-28.

25. Barzanji AT, Alamri FA, Mohamed AG. Osteoporosis: a study of knowledge, attitude and practice among adults in Riyadh, Saudi Arabia. J Community Health 2013;38:1098-105.

26. Yağmur Y. Evaluation of the efficiency og the health improvement program administered on young women for protection of osteoporosis. Inonu Univ Tıp Fak Derg. 2006;13:257-62.

27. Gelisli Y, Ersoy Y, Konokman GB. Determining the impact of nutrition training given to women on their knowledge amout osteoporosis. Procedia Soc Behav Sci 2009;1:2524-8.

28. Sayed-Hassan R, Bashour H, Koudsi A. Osteoporosis knowledge and attitudes: a cross-sectional study among female nursing school students in Damascus. Arch Osteoporos 2013;8:149.

29. Ford MA, Bass $M$, Zhao $Y$, Bai JB, Zhao $Y$. Osteoporosis Knowledge, Self-Efficacy, and Beliefs among College Students in the USA and China. J Osteoporos 2011:2011:729219.

30. Werner P. Knowledge about osteoporosis: assessment, correlates and outcomes. Osteoporos Int 2005:16:115-27.

31. Winzenberg TM, Oldenburg B, Frendin S, De Wit L, Jones G. Effects of bone density feedback and group education on osteoporosis knowledge and osteoporosis self-efficacy in premenopausal women: a randomized controlled trial. J Clin Densitom 2005;8:95-103

32. Endicott RD. Knowledge, Health Beliefs, and Self-Efficacy regarding Osteoporosis in Perimenopausal Women. J Osteoporos 2013:2013:853531. 